\title{
Effects of Public School Closures on Crime: The Case of the 2013 Chicago Mass School Closure
}

\author{
Noli Brazil \\ University of California, Davis
}

\begin{abstract}
Public school closures are increasing in number and size in U.S. cities. In response, parents, teachers, and public school advocates argue that closures carry negative consequences for multiple institutions across a wide set of outcomes. One such institution is the local neighborhood, and a negative consequence that is frequently raised is increased crime. I test this claim by using the 2013 Chicago mass school closure as a case study. Rather than conceiving of a school closure as a binary event (closed or not closed) I break it out according to a school's status after closure: vacant, repurposed, and merged with an existing school. I find that vacancy and repurposing into a nonschool are associated with decreased crime. In contrast, merging a closed school with an existing school is associated with increased crime. The vacancy and repurposing effects are spatiotemporally localized, concentrated in the 75-meter area surrounding the school and disappearing after a year, whereas the student merger effect persisted over time across larger spatial scales. My results suggest that the relationship between closure and neighborhood crime is not straightforward, varying by postclosure land use status and spatiotemporal factors.
\end{abstract}

Keywords: school closures; crime; neighborhoods; schools

Citation: Brazil, Noli. 2020. "Effects of Public School Closures on Crime: The Case of the 2013 Chicago Mass School Closure." Sociological Science 7: 128151.

Received: January 9, 2020

Accepted: February 22, 2020

Published: April 28, 2020

Editor(s): Jesper Sørensen, Olav Sorenson

DOI: $10.15195 / \mathrm{v} 7 . \mathrm{a} 6$

Copyright: (C) 2020 The Author(s). This open-access article has been published under a Creative Commons Attribution License, which allows unrestricted use, distribution and reproduction, in any form, as long as the original author and source have been credited. (C) (i)
T ARGE numbers of public schools have recently closed in cities across the United L States (Burdick-Will, Keels, and Schuble 2013; Weber, Farmer, and Donoghue 2020). From 2002 to 2011, the number of closures per 1,000 schools in the 100 largest metropolitan areas nearly doubled, increasing from 5.5 to 10.6 during this period (McFarland et al. 2017). The size of individual closure events is also substantial. For example, Detroit closed 93 schools between 2009 and 2014, Philadelphia closed 30 schools between 2012 and 2013, and Chicago experienced the largest mass school closure in U.S. history in 2013 when it closed 47 of its elementary schools. Urban closures have been met with fierce resistance, with teachers, families, and public school advocates organizing protests, holding hunger strikes, and filing lawsuits to save their schools. Despite the significant backlash, school district officials continue to close schools at an alarming rate, justifying the strategy as an efficient means for addressing fiscal constraints and increasing academic performance (Tieken and Auldridge-Reveles 2019).

Opponents of school closures counter claims of economic efficiency and academic accountability by arguing that school closures affect more institutions and actors than displaced students alone (Tieken and Auldridge-Reveles 2019). Therefore, public officials are underestimating the broader societal costs of closing a school. One such institution is the neighborhood, which has important economic and social interdependencies with local schools (Brazil 2016; Good 2019). A negative consequence for neighborhoods that is consistently raised is increased crime (Black 2018; Ewing 2018; Hagedorn 2017). This claim is based primarily on two 
mechanisms. First, according to broken windows theory, the disorder attached to school building vacancy after closure will attract crime to the area (Wilson and Kelling 1982). Second, displaced students are forced to cross rival gang territories to attend other schools, thus elevating community conflict and violence (Ahmed-Ullah 2013).

The relationship between closures and crime, however, is not as straightforward as it might appear. First, some theoretical perspectives view schools as generators of crime and thus would predict a decrease in crime after closure. For example, routine activity theory asserts that schools increase criminal opportunities in surrounding neighborhoods by concentrating suitable targets in the absence of capable guardianship (Cook 2017). Second, school closures are multicategorical phenomena, where categories are based on a school building's status after closure, either vacant, repurposed, or merged with an existing school. These conditions may have differential associations with neighborhood crime that are masked when examining closure as a binary event: closed or not closed. Third, the effects of a school closure may vary by status duration and distance to the closed school. Fourth, closures may impact neighborhoods that are indirectly affected by the district's closure policy. In particular, districts typically reassign displaced students to a welcoming school, which in turn may have consequences for that school's surrounding neighborhood. In cases where the receiving school remains in its existing location, vacancy occurs in the closed school's neighborhood, whereas student merger occurs in the receiving school's neighborhood. The scenario is switched when the welcoming school relocates to the closed school location. Depending on the nature of the relationship between crime, vacancy, and student merger, crime levels may increase in one place but decrease in another.

Examining the association between closures and neighborhood crime is further complicated by the nonrandom selection of schools for closure (Brazil 2019; Caven 2019; Lee and Lubienski 2017). I aim to mitigate this challenge by leveraging the 2013 Chicago mass school closure to estimate the effects of closures on local crime. In May 2013, Chicago Public Schools (CPS) voted to close 49 elementary schools. In addition to representing an important case deserving study in and of itself given its historic size, the Chicago mass school closure offers several methodological advantages. These advantages include its significant magnitude and compressed timeline, the formation of a valid comparison group based on the schools considered but not selected for closure, the five-year moratorium on school closures, and variation in postclosure status condition, specifically building vacancy, repurposing, and student merger. Using a monthly panel of crime counts between 2008 and 2018, I test the differential impact of school vacancy, repurposing, and merger on neighborhood crime as a consequence of Chicago's mass closure. I test the effects across varying spatial and temporal scales and differentiate between officially closed schools and nonclosed schools that were assigned to receive displaced students.

\section{How School Closures Affect Local Crime}

Conceptualizing the ways in which schools are repurposed after closure is central to understanding the theoretical pathways linking school closure to neighborhood 
crime. After a school is closed, its building can either become vacant or repurposed for another use. Because they are often large and located in residential neighborhoods, school buildings are difficult to sell and thus can remain vacant for long periods of time. If the district can find a buyer or renter, the building is often converted into a nonschool (e.g., housing or recreation center) or a new school (Dowdall and Warner 2013). Whether and how long a closed school building remains vacant and how the building is repurposed may have differential consequences on local crime.

Conceptualizing the indirect impact that closures may have on nonclosed schools and their neighborhoods is central to understanding how a city's school closure plan can produce spillover externalities. The primary mechanism through which closures impact other schools is through the reassignment of displaced students. Many school districts establish student reassignment plans that send displaced students to the nearest school or, in more limited cases, the nearest highperforming school, offering transportation options to those with limited geographic access. Here, the nonclosed school is the site of the merger and the closed school becomes vacant or repurposed. However, the district may relocate a welcoming school to the closed school's building, leaving a vacant building in the welcoming school's old neighborhood and forcing the welcoming school's students to travel across potentially unsafe areas. In either scenario (a welcoming school staying in place or relocating), school closures will have community-wide effects that go beyond the neighborhoods surrounding the closed schools.

By overlaying various theoretical perspectives onto the status conditions that schools enter after closure, I generate hypotheses regarding the effects of school closures on neighborhood crime. In the following sections, I rely on these various theoretical perspectives to explicate the pathways linking school closures to local crime.

\section{School Closures Increase Crime}

There are two mechanisms that support the hypothesis that school closures increase neighborhood crime. First, closures increase crime through school building vacancies. This pathway is supported by the broken windows theory, which posits that visual cues of disorder, such as abandoned buildings, attract crime because offenders assume from these cues that residents are indifferent to what goes on in the neighborhood (Wilson and Kelling 1982). Several studies have found support for this theory, estimating positive associations between property vacancies and criminal activity (Cui and Walsh 2015; Raleigh and Galster 2015). For example, Spelman (1993) found that crimes such as drug dealing and prostitution were found to take place within the confines of more than 80 percent of abandoned buildings. School buildings are more likely to remain vacant after closure because the typical urban school for sale is old, large, and located in a residential area, limiting its resaleability (Dowdall and Warner 2013). Furthermore, demolition is often more expensive than keeping buildings up and not maintaining them (Dowdall and Warner 2013). Abandoned buildings deteriorate, making them harder to resell, and become magnets for illicit activities. As one public official explained after the 
closure of several schools in Atlanta, "If you leave an old building sitting for so long, the water is not running, the gas line isn't working ... it makes it harder to redevelop them, making them a place for crime" (Sarrio 2012).

The second mechanism explaining an increase in crime after closure is the merging of displaced students with students from a welcoming school. A typical school district strategy for reenrolling displaced students is to send them to designated welcoming schools, where welcoming is determined by a number of factors, including enrollment, academic performance, and distance (Brummet 2014; Engberg et al. 2012; Steinberg, Ukert, and MacDonald 2019). The merger can occur in either the location of the welcoming school or the closed school. Public school advocates argue that crime increases because students travelling to a new school location have to cross rival gang boundaries (Hagedorn 2017).

In the case of Chicago, teachers and staff of welcoming schools substantiate these concerns, observing that when students are walking to and from school, they "have to be real careful because [they're] in two different gang territories, ... so sometimes [they] get chased home because they stayed on one side versus another around here" (Gordon et al. 2018:30). Students attending welcoming schools are aware of these dangers, reporting lower levels of safety walking to and from school compared to students enrolled in other schools (Gordon et al. 2018). Even if students are not affiliated with a gang, they may still be targeted solely because of where they live. As a Chicago alderman explained in reaction to the closing of his neighborhood elementary school, "It's not about if a kid is a gangbanger or not. It's about if they come from that community, that area. Then they're considered affiliated" (Konkol 2013). Urban gangs typically carve out turf at very small spatial scales, sometimes down to the block-by-block level (Papachristos, Hureau, and Braga 2013), thus forcing students to cross gang boundaries across relatively short distances. CPS offered additional busing only when welcoming schools were greater than 0.8 miles away. Even when students commute to school using busses, they must walk to bus stops, which are not always close to their home locations (Lee and Lubienski 2017). Whether walking to school or a bus stop, students living in the neighborhoods affected by Chicago's mass closure must traverse through some of the city's most violent areas. Fear of violence and direct exposure to crime have serious consequences on student wellbeing outcomes, including rates of absenteeism, which in turn may lead to other delinquent behaviors that may incite further strife within the community (Burdick-Will, Stein, and Grigg 2019; DaViera and Roy 2019; Sharkey et al. 2014).

\section{School Closures Decrease Crime}

An alternative hypothesis argues that school closures decrease crime. This prediction is supported by routine activity and social disorganization theories, which associate crime with patterns of land use and the spatial arrangement of facilities. Routine activity theory posits that patterns of land use have the potential to either facilitate or impede crime by structuring routine activities that create opportunities for offending or encourage social control in public places (Felson 1987). One way that schools might attract crime is by increasing the traffic density. Neighborhoods 
with a school experience a high ratio of nonresidents to residents as a result of the services provided by the school, which include noneducational services that are offered outside of school hours. As a result, schools have a tendency to yield a high volume of targets. Given that guardianship is mainly limited to school grounds and schools are dismissed several hours before most working adults return home, guardianship would be at a minimum within the community, allowing offenders opportunities to engage in theft, assault, and other crime with little chance of detection.

Criminologists have also used social disorganization theory to explain higher rates of crime in neighborhoods with schools. The theory hypothesizes that structural disadvantages such as poverty and residential turnover induce crime because of their ability to impede the development of social ties, mutual cohesion and trust, organizational participation, and the supervision of teenage groups (Sampson and Groves 1989). Wo and Park (2020) found support for this explanation in their study of crime around Chicago public schools. They argue that higher rates of crime may be attributed to the presence of schools inhibiting pro-social interaction between people living in the neighborhood, school staff, students and parents, thus separating the local community into different social worlds and thereby undermining the ability to informally monitor and regulate crime in public spaces around schools. Because of these dividing lines, responsibility over the supervision of neighborhood youth may be unclear, obstructing residents' ability to detect criminal activity. Although the presence of youth in the neighborhood may be due to nonschool reasons, some of which might be criminal in nature, residents may assume it is due to formal schooling obligations, thus shifting the responsibility out of their hands (Willits, Broidy, and Denman 2013). If a neighborhood does not have a school, as is the case when a school closes, "the activity patterns of residents and nonresidents will more readily converge, thereby prosocial interaction is more likely to occur" (Wo and Park 2020:4).

Studies have consistently demonstrated that the presence of schools influences crime patterns in the surrounding community (Astor, Benbenishty, and Meyer 2004; Kautt and Roncek 2007; Roncek 2000; Wo and Park 2020). However, these studies examine crime around active schools. In the case of school closures, the association with crime will depend on what happens to the school building after closure. For example, the decrease in crime caused by removing a criminogenic facility from the area may be counteracted if the school building becomes vacant and this vacancy leads to increased crime. The effects may also vary across temporal and spatial scales. Han (2014) found that the impact of abandoned properties on nearby property values declines as the distance from the abandoned property increases. However, when abandoned properties sit unoccupied for longer periods of time, their impact on nearby property values increases in magnitude and goes farther in distance. These spatiotemporal differences may also apply to the closure-crime relationship.

In the lone study examining the effects of traditional public school closures on crime, Steinberg et al. (2019) found substantive declines in crime following high school closure in Philadelphia. They argue that these findings are consistent with theories that predict crime to be higher with the presence of more students in an area 
by reducing the opportunity costs for crime and increasing the potential for criminal socialization. The student-as-offender argument is weaker in the case of elementary and middle school closures because the age group of primary school students has low criminal offending rates. The authors also found evidence that violent crime increases in neighborhoods where larger shares of enrolled students were displaced due to school closures. The study is an important first step to understanding the relationship between closures and crime, but it has yet to be replicated in another urban area. The current study examines the closure-crime relationship in Chicago and leverages several methodological advantages offered by the city's 2013 mass school closure.

\section{Chicago's 2013 Mass School Closure}

Confronted with budget woes, substandard building conditions, poor academic performance, declining populations, and a powerful education reform movement backing school choice as the primary vehicle for school reform, Chicago initiated several rounds of school closings during the 2000s, reaching its climax in the 20122013 school year, when CPS voted to close 49 elementary schools (Ewing 2018). As the largest mass school closure to date, generating significant public outcry, including mass protests and major lawsuits, Chicago's 2013 school closings merit scholarly examination. Important for this study's purposes, the evidence suggests that the mass closure also has a number of methodologically attractive features.

First, the mass closure provides a valid comparison group to the closed schools. In estimating the effects of school closures on neighborhood outcomes, the main econometric challenge is that closed schools are not randomly selected. CPS cited many different factors when selecting which schools to close; among them were enrollment, performance measures, and the overall condition of the school buildings (De la Torre et al. 2015). The selection of schools also incorporated unobserved characteristics, including public and private feedback from various stakeholders. Closed schools are not randomly scattered across the city, as most are concentrated in disadvantaged neighborhoods in the south and west sides (see Figure 1). A naive comparison of crime rates in neighborhoods that experienced a closure with the crime rates in neighborhoods that did not experience a closure is likely to yield biased estimates.

This article's solution is to rely on the final CPS-announced list of schools considered for closure. In December 2012, CPS identified 330 schools that were underenrolled and at risk for closure. This initial list included elementary schools, high schools, and charter schools, regardless of school performance. After a short period of public discussion, a pared down list of 129 elementary schools that could be closed was released in February 2013. Most of the schools slated for closure were located in historically disinvested and primarily black communities. In May 2013, the Chicago Board of Education voted to close 49 of the 129 elementary schools. ${ }^{1}$ The identifying assumption is that the schools in the February 2013 list that were not selected for closure form a valid counterfactual for the schools that were selected after conditioning on differences in preexisting trends. 


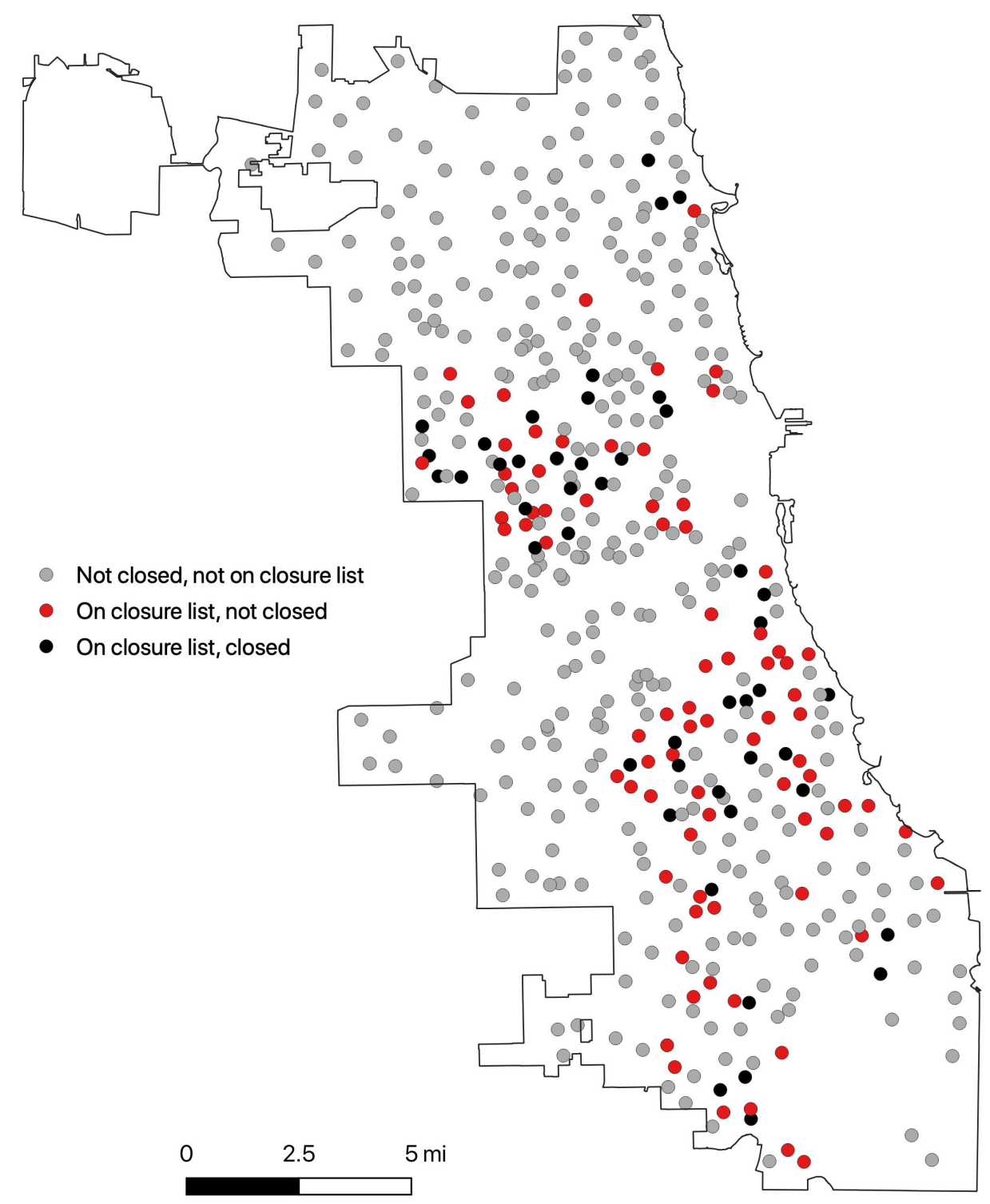

Figure 1: Chicago public elementary school locations in 2013. Mi, miles. 
To examine how well my approach identifies similar treatment and control areas, Table 1 compares school and census tract characteristics of the 49 schools that were closed, the 413 schools that were not closed, and the 79 schools that were not closed but appeared on the February 2013 list. The school data reflect the 2012-2013 school year and come from CPS. Neighborhoods are represented as census tracts containing an elementary school. Tract data come from the 2009-2013 American Community Survey. I ran a series of ordinary least squares regressions for each of these variables on the closure indicator to determine whether differences between the closed schools and the two sets of controls are statistically significant. I find that closed schools have a significantly different demographic makeup and much lower standardized test scores compared to all nonclosed schools. They are also located in significantly poorer neighborhoods with a greater presence of black residents. In contrast, the 79 schools on the February closure list that did not close have similar school- and tract-level characteristics. These schools also exhibit similar premass closure crime levels. Table 2 compares the mean pre-2013 violent and nonviolent crime counts across the three groups by the circular distance in meters around the school. The preclosure violent and nonviolent crime mean counts are lower in the all nonclosed schools group across all radii. In contrast, mean crime counts for areas surrounding non-closed schools on the February list are similar to the areas surrounding closed schools. The results shown in Tables 1 and 2 suggest that nonclosed schools that appeared on the February 2013 list constitute a better comparison group than all nonclosed schools based on the similarity of preclosure observable characteristics and crime levels.

A second important feature of the mass closure is the significant limitations in the district's planning and execution of the closure process (Ewing 2018). These limitations are connected to the district's aggressive closure timeline. Communities had only three months to discuss and respond to the district's February list. After the Board of Education vote took place at the end of May, there was only one month until the end of the school year and only two months thereafter to prepare for the new school year. An Illinois state report issued by the Chicago Educational Facilities Task Force (2014) outlined other deficiencies: input from broader community stakeholders was missing in engagement sessions; district officials often rejected the feedback and advice of independent hearing officers when they disagreed with a proposed action; little planning surrounding the use of school buildings after closure; and failure to properly assess and monitor the impact of the closures on students, staff, and surrounding communities. Moreover, although CPS formulated a strategy for reenrolling displaced students, it offered no after-closure plans for the communities served by closed schools. The report concluded that the process lacked long-range planning and adequate community engagement. The report's findings are supported by school staff interviews that suggested little guidance from the district on how to prepare for large influxes of new staff and students coming from different school and neighborhood communities (Gordon et al. 2018). These factors, along with the significant size of the closures (the percentage of the district's schools and students impacted by the closure are 10.6 percent and 6.0 percent, respectively), suggest that many communities were ill prepared for absorbing the wider effects of 
Table 1: Mean characteristics of Chicago public elementary schools and their tracts by 2013 closure status.

\begin{tabular}{|c|c|c|c|}
\hline Variable & $\begin{array}{l}\text { Closed } \\
\text { schools }\end{array}$ & $\begin{array}{l}\text { All nonclosed } \\
\text { closed schools }\end{array}$ & $\begin{array}{c}\text { Nonclosed } \\
\text { schools on } \\
\text { February } 2013 \text { list }\end{array}$ \\
\hline \multicolumn{4}{|l|}{ School characteristics } \\
\hline Average enrollment & 297.6 & $589.7^{\dagger}$ & $363.9^{+}$ \\
\hline Average reading score & 26.8 & $41.7^{+}$ & 26.0 \\
\hline Average math score & 31.3 & $46.5^{+}$ & 31.5 \\
\hline$\%$ white & 0.9 & $10.7^{*}$ & 1.1 \\
\hline$\%$ black & 86.8 & $34.3^{+}$ & 87.9 \\
\hline$\%$ Hispanic & 10.2 & $48.8^{+}$ & 9.4 \\
\hline \multicolumn{4}{|l|}{ Tract characteristics } \\
\hline Average population & $3,043.8$ & $3,840.9^{\dagger}$ & $2,952.2$ \\
\hline$\%<18$ years old & 26.1 & $24.8 *$ & 25.9 \\
\hline$\%$ not moving in past year & 80.7 & $85.7^{*}$ & 83.7 \\
\hline$\%$ female-headed households & 52.4 & $34.0^{+}$ & 54.1 \\
\hline$\%$ bachelor's degree & 24.4 & $28.1^{*}$ & 21.9 \\
\hline$\%$ unemployed & 21.4 & $15.2^{+}$ & 23.1 \\
\hline$\%$ poverty & 35.8 & $23.9^{+}$ & 33.7 \\
\hline$\%$ white & 12.4 & $25.6^{+}$ & 9.5 \\
\hline \% black & 74.0 & $37.7^{+}$ & 78.8 \\
\hline$\%$ Hispanic & 10.1 & $30.6^{+}$ & 8.4 \\
\hline $\mathrm{N}$ & 49 & 413 & 79 \\
\hline
\end{tabular}

All neighborhood characteristics are measured for the 2009-2013 period at the tract level. Asterisks in columns 3 and 4 indicate whether mean values statistically differ from the mean values for the closed schools group. $+p<0.01,{ }^{*} p<0.05$.

the closures. In other words, a closure was arguably a significant and unexpected shock to a community.

The third important feature of the mass closure is that CPS instituted a five-year moratorium on school closings. Identification requires that there are no other confounding events that also affect crime. The moratorium means that I can observe the five-year impact of the school closures without subsequent closures contaminating the estimates. I can compare crime trends postclosure without the influence of other closures occurring during the postclosure period that would likely affect the remaining open schools and their neighborhoods.

The final important feature is the school district's reenrollment plan for displaced students. In order to accommodate the nearly 12,000 displaced students affected by the mass closure, CPS designated specific welcoming schools for each of the closed schools. A welcoming school had to be within one mile of the closed school, perform better than the closed school, and have enough available seats to accommodate students. The potential impact of the merger is significant, as, on average, the welcoming schools each received approximately 150 displaced students, accounting for about 32 percent of their student population in fall 2013 (Gordon et al. 2018). For some of the welcoming schools, their enrollments almost doubled in size. Students merged together were typically coming from neighborhoods with rival youth 
Table 2: Mean crime counts by school-buffer radius before June 2013.

\begin{tabular}{lcccc}
\hline Crime & Closed & $\begin{array}{c}\text { All nonclosed } \\
\text { closed schools }\end{array}$ & $\begin{array}{c}\text { Nonclosed } \\
\text { schools on } \\
\text { February 2013 list }\end{array}$ \\
\hline Violent & 75 & 0.2 & $0.1^{\dagger}$ & 0.2 \\
& 150 & 0.8 & $0.5^{\dagger}$ & 0.7 \\
& 300 & 3.0 & $1.9^{\dagger}$ & 2.8 \\
Nonviolent & 450 & 6.8 & $4.3^{\dagger}$ & 6.2 \\
& 75 & 2.1 & $1.4^{\dagger}$ & 1.9 \\
& 150 & 8.0 & $4.9^{\dagger}$ & 6.7 \\
$\mathrm{~N}$ & 300 & 29.9 & $19.1^{\dagger}$ & 25.5 \\
& 450 & 65.1 & $43.1^{\dagger}$ & 56.8 \\
\hline
\end{tabular}

Asterisks in columns 4 and 5 indicate whether mean values statistically differ from the mean values for the closed schools group. $+p<0.01,{ }^{*} p<0.05$.

gangs, and the district's Office of Safety and Security was largely unaware of these boundaries (Ewing 2018). Moreover, some welcoming schools received displaced students in their current locations, whereas CPS determined that the closed school building will house the welcoming school, leaving their previous neighborhoods with building vacancies to fill and forcing welcoming school staff and students to commute. Students enrolled in welcoming schools reported feeling less safe walking to and from school compared to students in other schools across the district (Gordon et al. 2018). The concern regarding the crossing of gang boundaries was not relegated to teachers and parents, as the CPS expanded its Safe Passage Program, which places adult monitors along designated "safe passage" streets leading to and from welcoming schools. Despite claims by the CPS that the program led to a substantial decline in crime, evidence suggests much smaller declines only in particular safe-passage street segments and no change in crime around safe-passage schools (Curran 2019).

\section{Empirical Approach}

\section{Data Sources}

I collected data on the 464 elementary schools open in the 2012-2013 school year from CPS. I then identified the 129 elementary schools initially considered for closure in February 2013 and the 49 that were ultimately voted for closure in May 2013. I also identified the 48 welcoming schools (schools that were selected to receive displaced students), linking them to the closed schools whose students they were welcoming. I also identified whether welcoming schools relocated to another building. I excluded from the sample a welcoming school that unofficially closed during the five-year moratorium. The list of elementary schools considered for closure in February 2013, school longitude and latitude coordinates, and welcoming school information were obtained from CPS. The sales date and new ownership of 
each abandoned school building were collected from CPS, newspaper articles, and media documentation of school building sales. ${ }^{2}$ The study's observation period is July 2008 to July 2018, representing the five-year period before and after the mass school closure.

Crime incident data were collected from Chicago's online open data portal. The data include the type of crime as classified under the Uniform Crime Reporting Program, geographic location, and date of each crime from July 2008 to July 2018. A total of 282,373 violent and 2,898,693 nonviolent crimes are included in the 10 years covered by the data. Violent crimes include homicide, rape, aggravated assault and battery, and robbery. Figure 2 shows yearly Chicago violent and nonviolent crime rates per 10,000 population from 2008 to 2018. Violent crime rates steadily decreased from 132.1 to 83.3 from 2008 to 2014, went back up to 103.9 in 2016, but then dipped to 94.4 in 2018. Nonviolent crime rates show a steady decline from 2008 to 2015, dropping from $14,249.3$ to 8709.6 , but then flatten out the rest of the study period. Crime rates generally went down, but Figure 3 shows that the spatial distribution of crime did not significantly change from 2008 to 2018, as the most and least dangerous neighborhoods remained so during the period (Papachristos, Brazil, and Cheng 2018).

\section{Estimation Strategy}

I constructed a panel data set containing monthly crime for the neighborhoods surrounding public elementary schools on the February 2013 list. My definition of a neighborhood is a circular buffer of radius $r$ surrounding each elementary school. The more localized definition of neighborhood compared to larger traditional census measures such as tracts controls for neighborhood characteristics that increasingly become dissimilar as the geographic scale increases. A buffer also places the school at the center of the neighborhood, whereas a census tract or block group measure places some schools near the boundary, thus misestimating the effects if there are spillover consequences. Moreover, a buffer allows for the testing of differential effects by spatial scale.

Following prior work examining the impact of vacant properties on local crime (Cui and Walsh 2015), I tested several radii $r$, specifically $r=75,150,300$, and 450 meters. The different radii provide a balance between the noisier estimates of smaller areas and the increased differences between those treated and controls as the buffer zones increase. I then spatially joined crime data to each buffer. The specification for the empirical analysis is presented in the following equation.

$$
\text { Crime }_{i m y}=\alpha+\beta^{1} D_{i m y}^{1}+\beta^{2} D_{i m y}^{2}+\beta^{3} D_{i m y}^{3}+\beta^{4} D_{i m y}^{4}+\gamma_{i}+\vartheta_{m y}+\epsilon_{i m y}
$$

where Crime $e_{i m y}$ is the number of violent or nonviolent crimes within the circular school buffer $i$ in month $m$ and year $y, \gamma_{i}$ is a school buffer fixed effect and controls for time-invariant area characteristics, and $\vartheta_{m y}$ is a month-by-year fixed effect controlling for all month-by-year trends confounding the relationship between crime and closure. Because the outcome variable is a nonnegative count, I ran negative binomial regression models using maximum likelihood methods to estimate equation 


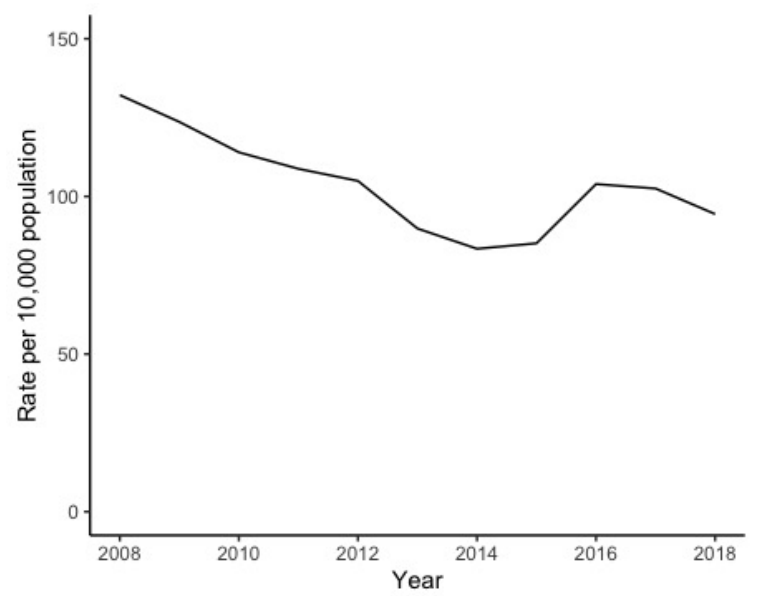

(a) Violent crime

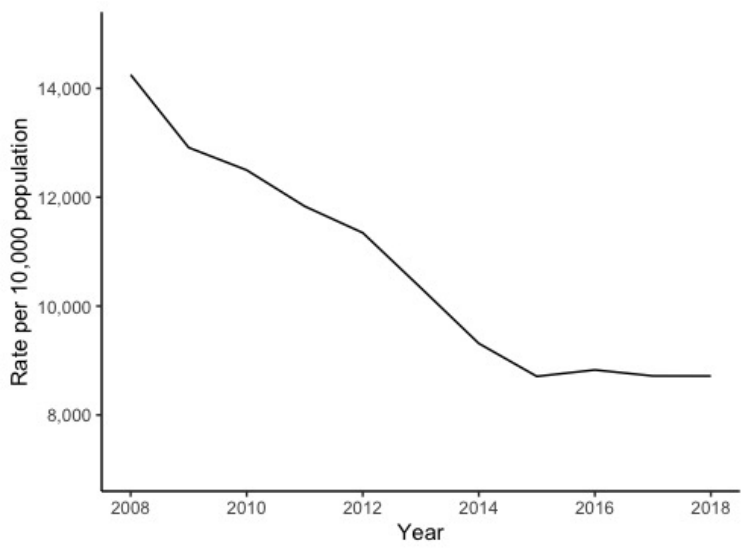

(b) Non-violent crime

Figure 2: Violent and nonviolent crimes per 10,000 population in Chicago, 2008-2018.

1, with the number of buildings in 2013 within the circular buffer as the measure of exposure. I clustered standard errors by school buffer.

The variable $D_{i m y}$ categorizes neighborhoods into the following five postclosure status conditions (with the proportion of school buffer-by-month observations in parentheses): the school experienced no change (reference; 75.3 percent); the school merged (8.4 percent); the school is vacant (10.4 percent); the school was repurposed into a nonschool (3.1 percent); and the school was repurposed into a nonwelcoming school (2.9 percent). The last category contains existing schools enrolling nonelementary school students that took over the vacant school buildings. For example, The Chicago High School for the Arts took over Lafayette Elementary School, and Kenwood Academy High School relocated into Canter Middle School. No new schools opened in closed buildings during the study period, and the district prohibited reoccupation by charters during the moratorium. Two schools were selected for closure in May 2013 but did not officially close until a later date. I designated the other 47 schools as closed in July 2013, with the last day of the 2012-2013 school year falling on June 17. The 2013-2014 school year officially began on August 26, 2013. School locations experiencing a merger of students were designated as such starting September 2013. School buildings leased or sold to a new owner were designated as such in the month and year of their sale dates.

\section{Results}

\section{The Effects of School Vacancy, Merger, and Repurposing}

Table 3 presents the main coefficients of interest from the estimation of equation 1. Each panel represents separate models based on violent and nonviolent crime as the dependent variable. The columns represent separate models based on buffer size. I present the coefficients as incidence rate ratios (IRRs). An IRR less than 1 


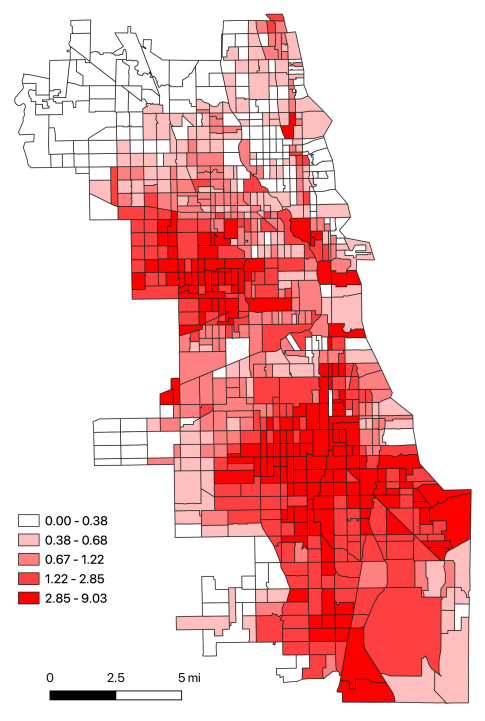

(a) Violent 2008

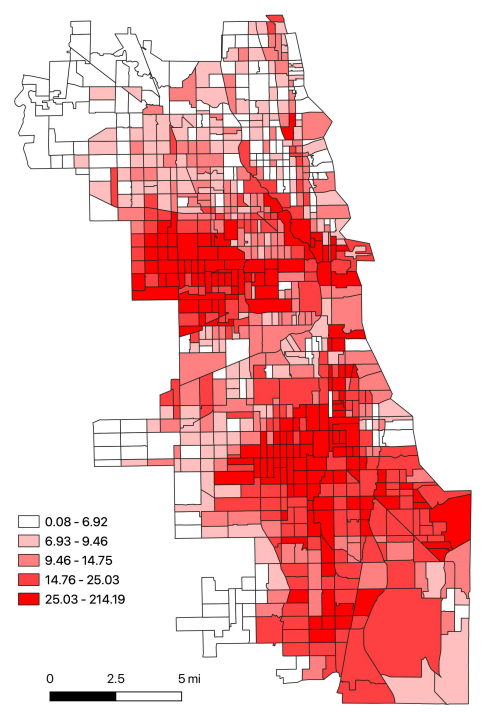

(c) Non-violent 2008

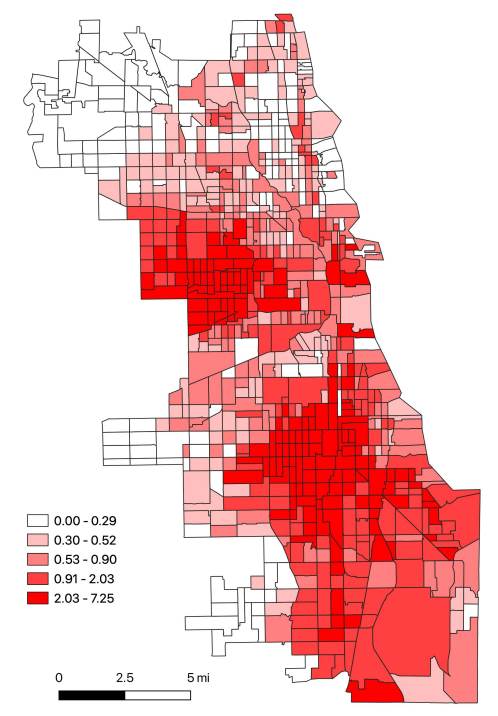

(b) Violent 2018

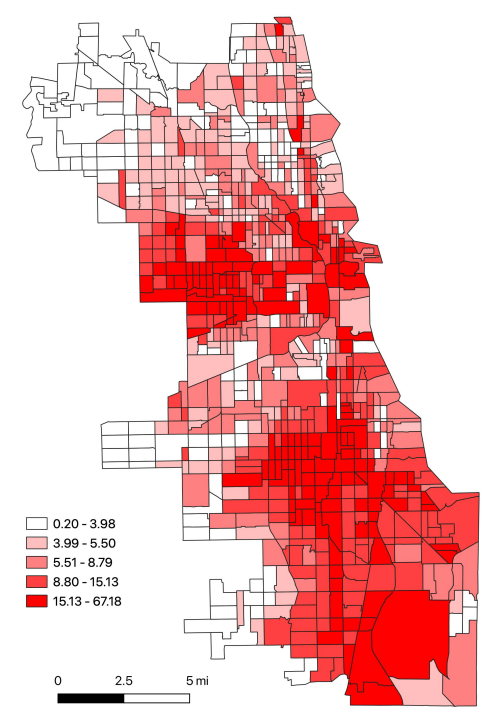

(d) Non-violent 2018

Figure 3: Violent and nonviolent crime rates per 100 population by census tract, 2008 and 2018. Mi, miles. 
Table 3: Results from negative binomial regressions of violent and nonviolent crime counts on school closure condition by buffer radius.

\begin{tabular}{lcccc}
\hline & 75 & 150 & 300 & 450 \\
\hline Panel A: Violent Crime & & & & \\
Merged & 1.15 & 1.16 & 1.04 & 1.04 \\
& $(0.15)$ & $(0.09)$ & $(0.07)$ & $(0.05)$ \\
Vacant & 0.78 & 0.92 & 0.92 & 0.97 \\
& $(0.11)$ & $(0.06)$ & $(0.05)$ & $(0.04)$ \\
Repurposed nonschool & 1.22 & 1.07 & 1.01 & 0.98 \\
& $(0.18)$ & $(0.09)$ & $(0.07)$ & $(0.05)$ \\
Repurposed nonmerged school & 1.30 & 1.00 & 1.02 & 1.06 \\
& $(0.30)$ & $(0.09)$ & $(0.07)$ & $(0.07)$ \\
Panel B: Nonviolent Crime & & & & 1.01 \\
Merged & $1.44^{\dagger}$ & $1.23^{\dagger}$ & $1.04^{*}$ & $(0.04)$ \\
& $(0.12)$ & $(0.07)$ & $(0.05)$ & 0.98 \\
Vacant & $0.65^{\dagger}$ & 0.95 & 0.96 & $(0.03)$ \\
& $(0.07)$ & $(0.05)$ & $(0.03)$ & 0.97 \\
Repurposed nonschool & $0.67^{\dagger}$ & 0.96 & 0.96 & $(0.04)$ \\
& $(0.07)$ & $(0.07)$ & $(0.04)$ & $(0.08$ \\
Repurposed nonmerged school & 1.06 & 0.96 & 0.99 & $(0.05)$ \\
& $(0.09)$ & $(0.09)$ & & \\
\hline
\end{tabular}

All models include school buffer and month-by-year fixed effects. Sample represents 15,488 buffer-bymonth-by-year observations representing 128 schools. Clustered standard errors are in parentheses. $t p<$ $0.01,{ }^{*} p<0.05$.

indicates a reduction in crime, whereas an IRR greater than 1 suggests an increase. The reference group in all models includes neighborhoods with schools that did not close and were not welcoming schools. The results shown in panel A reveal no effects on violent crime across all status conditions and buffer sizes. In contrast, I find several statistically significant and contrasting associations between school status and nonviolent crime. First, I find that merged school locations experienced an increase in nonviolent crime at the 75-meter scale. The regression coefficient indicates that a neighborhood experienced a 44 percent increase in nonviolent crime in the five years after a school merger. Second, I find that the increase, although declining in magnitude, persists at the 150-meter (22 percent) and 300-meter (4 percent) scales. These findings support arguments offered by teachers, students, parents, and public school advocates that closures increase local crime through the merger of student populations. The persistence of the effect across larger distances suggests explanatory mechanisms such as commuting across gang boundaries that go beyond something about the area immediately surrounding the school.

Third, I find an opposite effect (decreased nonviolent crime) in the 75-meter areas surrounding schools that are vacant. These neighborhoods experienced a 35 percent decrease in nonviolent crime. However, this effect is only significant at the smallest spatial scale. Fourth, neighborhoods surrounding schools that were repurposed into a nonschool experienced a 33 percent decrease in nonviolent crime. Similar to the vacancy effect, the decrease disappears after the 75-meter radius. 
These findings support routine activity and social disorganization theories, which identify schools as criminogenic facilities. However, the results suggest that the impact of land use conditions (vacancy and nonschool reoccupation) is limited to the area immediately surrounding the school. In contrast, the effect of student merger has broader geographic consequences.

I ran a set of additional models to test the robustness of the main results. First, in order to test whether findings are sensitive to distributional assumptions, I fitted Poisson models to go along with the negative binomial models presented in the main analysis. Second, I included a buffer-area-specific linear time trend to control for differential crime trends. Third, I explored the impact of extending the starting month of vacancy status. The main models designated a school as vacant one month after closure or relocation; therefore, schools that officially closed or relocated in June 2013 are designated as vacant starting in July 2013. I tested models that pushed vacancy status to one (August) and two (September) months after closure/relocation. The results from these robustness tests, which are provided in the online supplement, are similar to those presented in Table 3.

\section{Duration of Vacancy and Merger}

The models estimated in Table 3 do not take into account any varying effects by duration spent in a specific condition. I next present results from models that measure the effects of vacancy and merger duration on crime. In the case of building vacancy, prior evidence has shown that the effects of property abandonment on neighborhood outcomes such as crime vary by vacancy length (Cui and Walsh 2015; Han 2014). According to broken windows theory, the mechanism by which a distressed property influences crime is largely visual. Then, it is plausible to assume that the impact of a recently vacant school building may not be as strong as the impact of a school building that has been siting unmaintained for a much longer period. On the one hand, a smaller or no effect occurs in the earlier period but increases or emerges the longer the building remains vacant. On the other hand, a negative effect may occur in the earlier period due to the immediate displacement of students as offenders and victims, but the effect either disappears as the local area adjusts to the vacant property or becomes positive if the vacant property attracts crime.

To examine the effect of vacancy length on crime, I estimated equation 1 using the same treatment variable $D_{i m y}$ but expanded the vacancy status condition into the following categories: school building is vacant less than 12 months, between 12 and 23 months, and greater than or equal to 24 months. Results are shown in Table 4. I find that the results in Table 3 were masking a short-term effect on violent crime. Here, there is a 34 percent decrease in violent crime in the first year at the 75-meter scale. This negative effect is significant but decreases in magnitude at larger spatial scales. I also find a decrease in nonviolent crime but only at the 75meter scale. This effect persists after a year (36 percent decrease), becomes smaller in the second year (28 percent), and disappears thereafter. These results expand the main findings from Table 3 by showing that the effects of vacancy on crime are not only spatially localized but short term. This finding may suggest that the negative 
Table 4: Results from negative binomial regressions of violent and nonviolent crime counts on school closure condition by buffer radius and vacancy duration.

\begin{tabular}{|c|c|c|c|c|}
\hline & 75 & 150 & 300 & 450 \\
\hline \multicolumn{5}{|l|}{ Panel A: Violent Crime } \\
\hline \multicolumn{5}{|l|}{ Vacancy duration } \\
\hline \multirow[t]{2}{*}{$<12$ months } & $0.66^{*}$ & $0.82^{*}$ & $0.87^{*}$ & $0.89^{\dagger}$ \\
\hline & $(0.13)$ & $(0.08)$ & $(0.05)$ & $(0.03)$ \\
\hline \multirow[t]{2}{*}{ 12-23 months } & 0.82 & 0.95 & 0.92 & 0.93 \\
\hline & $(0.15)$ & $(0.09)$ & $(0.05)$ & $(0.04)$ \\
\hline \multirow[t]{2}{*}{$\geq 24$ months } & 0.82 & 0.96 & 0.95 & 1.02 \\
\hline & $(0.13)$ & $(0.07)$ & $(0.06)$ & $(0.05)$ \\
\hline \multirow[t]{2}{*}{ Merged } & 1.16 & 1.16 & 1.04 & 1.04 \\
\hline & $(0.15)$ & $(0.09)$ & $(0.07)$ & $(0.06)$ \\
\hline \multirow[t]{2}{*}{ Repurposed nonschool } & 1.23 & 1.07 & 1.01 & 0.98 \\
\hline & $(0.18)$ & $(0.10)$ & $(0.07)$ & $(0.05)$ \\
\hline \multirow[t]{2}{*}{ Repurposed nonmerged school } & 1.30 & 1.00 & 1.02 & 1.06 \\
\hline & $(0.29)$ & $(0.09)$ & $(0.07)$ & $(0.07)$ \\
\hline \multicolumn{5}{|l|}{ Panel B: Nonviolent Crime } \\
\hline \multicolumn{5}{|l|}{ Vacancy duration } \\
\hline \multirow[t]{2}{*}{$<12$ months } & $0.64^{\dagger}$ & 0.90 & 0.94 & 0.97 \\
\hline & $(0.07)$ & $(0.05)$ & $(0.04)$ & $(0.03)$ \\
\hline \multirow[t]{2}{*}{ 12-23 months } & $0.72^{\dagger}$ & 0.98 & 0.99 & 0.98 \\
\hline & $(0.08)$ & $(0.06)$ & $(0.04)$ & $(0.03)$ \\
\hline \multirow[t]{2}{*}{$\geq 24$ months } & 0.91 & 0.97 & 0.97 & 0.99 \\
\hline & $(0.07)$ & $(0.05)$ & $(0.04)$ & $(0.04)$ \\
\hline \multirow[t]{2}{*}{ Merged } & $1.44^{\dagger}$ & $1.23^{\dagger}$ & $1.04^{*}$ & 1.01 \\
\hline & $(0.12)$ & $(0.07)$ & $(0.05)$ & $(0.04)$ \\
\hline \multirow[t]{2}{*}{ Repurposed nonschool } & $0.67^{+}$ & 0.97 & 0.96 & 0.97 \\
\hline & $(0.07)$ & $(0.07)$ & $(0.04)$ & $(0.04)$ \\
\hline \multirow{2}{*}{ Repurposed nonmerged school } & 1.06 & 0.96 & 0.99 & 1.08 \\
\hline & $(0.09)$ & $(0.09)$ & $(0.05)$ & $(0.05)$ \\
\hline
\end{tabular}

All models include school buffer and month-by-year fixed effects. Sample represents 15,488 buffer-bymonth-by-year observations representing 128 schools. Clustered standard errors are in parentheses. $+p<$ $0.01,{ }^{*} p<0.05$.

consequences of vacancy as predicted by broken windows theory wash out the positive benefits of removing a criminogenic facility as predicted by routine activity and social disorganization theories if the building remains vacant long enough.

I next consider the length of time since school merger. On the one hand, given the short period of time to prepare for the merger, we might see an increase in crime in the short term but the effect disappearing in the long term as the surrounding community adjusts. On the other hand, the effect might persist or unfold later as new student rivalries and conflicts emerge after a transition period. Table 5 shows results from models estimating the effects of time since merger. To be consistent with the vacancy duration models, I categorized time since merger as less than 12 months, between 12 and 23 months, and greater than or equal to 24 months. 
Table 5: Results from negative binomial regressions of violent and nonviolent crime counts on school closure condition by buffer radius and merger duration.

\begin{tabular}{|c|c|c|c|c|}
\hline & 75 & 150 & 300 & 450 \\
\hline \multicolumn{5}{|l|}{ Panel A: Violent Crime } \\
\hline \multicolumn{5}{|l|}{ Merger duration } \\
\hline \multirow[t]{2}{*}{$<12$ months } & 1.06 & 1.15 & 1.02 & 1.02 \\
\hline & $(0.22)$ & $(0.14)$ & $(0.08)$ & $(0.06)$ \\
\hline \multirow[t]{2}{*}{ 12-23 months } & 1.04 & 1.05 & 1.05 & 1.09 \\
\hline & $(0.23)$ & $(0.14)$ & $(0.08)$ & $(0.06)$ \\
\hline \multirow[t]{2}{*}{$\geq 24$ months } & 1.22 & 1.19 & 1.05 & 1.03 \\
\hline & $(0.18)$ & $(0.11)$ & $(0.07)$ & $(0.06)$ \\
\hline \multirow[t]{2}{*}{ Vacant } & 0.78 & 0.92 & 0.92 & 0.97 \\
\hline & $(0.11)$ & $(0.06)$ & $(0.05)$ & $(0.04)$ \\
\hline \multirow[t]{2}{*}{ Repurposed nonschool } & 1.24 & 1.07 & 1.01 & 0.98 \\
\hline & $(0.18)$ & $(0.10)$ & $(0.07)$ & $(0.05)$ \\
\hline \multirow[t]{2}{*}{ Repurposed nonmerged school } & 1.30 & 1.00 & 1.02 & 1.06 \\
\hline & $(0.30)$ & $(0.09)$ & $(0.07)$ & $(0.07)$ \\
\hline \multicolumn{5}{|l|}{ Panel B: Nonviolent Crime } \\
\hline \multicolumn{5}{|l|}{ Merger duration } \\
\hline \multirow[t]{2}{*}{$<12$ months } & $1.52^{+}$ & $1.32^{+}$ & $1.07^{*}$ & 1.05 \\
\hline & $(0.14)$ & $(0.09)$ & $(0.05)$ & $(0.05)$ \\
\hline \multirow[t]{2}{*}{ 12-23 months } & $1.32 *$ & $1.19^{*}$ & $1.04^{*}$ & 1.02 \\
\hline & $(0.17)$ & $(0.11)$ & $(0.05)$ & $(0.05)$ \\
\hline \multirow[t]{2}{*}{$\geq 24$ months } & $1.46^{+}$ & $1.21^{\dagger}$ & 1.02 & 1.00 \\
\hline & $(0.13)$ & $(0.07)$ & $(0.06)$ & $(0.04)$ \\
\hline \multirow[t]{2}{*}{ Vacant } & $0.65^{+}$ & 0.95 & 0.96 & 0.98 \\
\hline & $(0.07)$ & $(0.05)$ & $(0.03)$ & $(0.03)$ \\
\hline \multirow[t]{2}{*}{ Repurposed no-school } & $0.67^{\dagger}$ & 0.96 & 0.96 & 0.97 \\
\hline & $(0.07)$ & $(0.07)$ & $(0.04)$ & $(0.04)$ \\
\hline \multirow[t]{2}{*}{ Repurposed nonmerged school } & 1.06 & 0.96 & 0.99 & 1.08 \\
\hline & $(0.09)$ & $(0.09)$ & $(0.05)$ & $(0.05)$ \\
\hline
\end{tabular}

All models include school buffer and month-by-year fixed effects. Sample represents 15,488 buffer-bymonth-by-year observations representing 128 schools. Clustered standard errors are in parentheses. $t p<$ $0.01,{ }^{*} p<0.05$.

I find that neighborhoods with merged schools experienced no change in violent crime across all time periods and buffer sizes. In contrast, I find a persistent increase in nonviolent crime across time at the 75-, 150-, and 300-meter scales. Nonviolent crime increased by 52 percent in the first year after merger at the 75-meter scale. This increase diminished in the second year (32 percent) but increased thereafter (46 percent). At the 150-meter scale, neighborhoods with a merged school experienced a 32 percent increase in nonviolent crime in the first year of merger. The increase is 18 percent and 20 percent in the second year and thereafter, respectively. I also find a persistent albeit smaller increase in nonviolent crime at the 300-meter buffer. Neighborhoods within 300 meters of a merged school experienced a 7 percent and 4 percent increase in nonviolent crime in the first and second year after 
Table 6: Results from negative binomial regressions of violent and nonviolent crime counts on school closure condition by buffer radius and welcoming and closed school location.

\begin{tabular}{|c|c|c|c|c|}
\hline & 75 & 150 & 300 & 450 \\
\hline \multicolumn{5}{|l|}{ Panel A: Violent Crime } \\
\hline Merged & $\begin{array}{c}0.93 \\
(0.22)\end{array}$ & $\begin{array}{c}1.20 \\
(0.20)\end{array}$ & $\begin{array}{l}1.03 \\
(0.10)\end{array}$ & $\begin{array}{l}1.03 \\
(0.06)\end{array}$ \\
\hline Vacant & $\begin{array}{c}0.63 \\
(0.15)\end{array}$ & $\begin{array}{c}0.91 \\
(0.11)\end{array}$ & $\begin{array}{c}0.87 \\
(0.09)\end{array}$ & $\begin{array}{r}0.93 \\
(0.07)\end{array}$ \\
\hline \multicolumn{5}{|l|}{ Closed school location } \\
\hline Merged & $\begin{array}{c}1.23 \\
(0.17)\end{array}$ & $\begin{array}{l}1.15 \\
(0.10)\end{array}$ & $\begin{array}{l}1.05 \\
(0.08)\end{array}$ & $\begin{array}{r}1.04 \\
(0.07)\end{array}$ \\
\hline Vacant & $\begin{array}{c}0.81 \\
(0.12)\end{array}$ & $\begin{array}{c}0.93 \\
(0.07)\end{array}$ & $\begin{array}{c}0.94 \\
(0.05)\end{array}$ & $\begin{array}{r}0.98 \\
(0.04)\end{array}$ \\
\hline Repurposed nonschool & $\begin{array}{c}1.22 \\
(0.18)\end{array}$ & $\begin{array}{l}1.08 \\
(0.10)\end{array}$ & $\begin{array}{c}1.01 \\
(0.07)\end{array}$ & $\begin{array}{r}0.98 \\
(0.05)\end{array}$ \\
\hline Repurposed nonmerged school & $\begin{array}{c}1.19 \\
(0.25)\end{array}$ & $\begin{array}{l}1.06 \\
(0.09)\end{array}$ & $\begin{array}{l}1.02 \\
(0.07)\end{array}$ & $\begin{array}{c}1.04 \\
(0.06)\end{array}$ \\
\hline $\begin{array}{l}\text { Panel B: Nonviolent Crime } \\
\text { Welcoming school location }\end{array}$ & & & & \\
\hline Merged & $\begin{array}{r}1.20^{*} \\
(0.14)\end{array}$ & $\begin{array}{r}1.13^{*} \\
(0.07)\end{array}$ & $\begin{array}{l}1.04^{*} \\
(0.04)\end{array}$ & $\begin{array}{c}0.97 \\
(0.04)\end{array}$ \\
\hline Vacant & $\begin{array}{r}0.69 * \\
(0.12)\end{array}$ & $\begin{array}{c}1.03 \\
(0.08)\end{array}$ & $\begin{array}{c}0.94 \\
(0.07)\end{array}$ & $\begin{array}{r}0.97 \\
(0.07)\end{array}$ \\
\hline Closed school location & & & & \\
\hline Merged & $\begin{array}{r}1.55^{\dagger} \\
(0.14)\end{array}$ & $\begin{array}{r}1.27^{+} \\
(0.08)\end{array}$ & $\begin{array}{r}1.07^{*} \\
(0.05)\end{array}$ & $\begin{array}{r}1.04 \\
(0.06)\end{array}$ \\
\hline Vacant & $\begin{array}{r}0.64^{+} \\
(0.07)\end{array}$ & $\begin{array}{c}0.93 \\
(0.05)\end{array}$ & $\begin{array}{c}0.97 \\
(0.03)\end{array}$ & $\begin{array}{r}0.99 \\
(0.03)\end{array}$ \\
\hline Repurposed nonschool & $\begin{array}{r}0.67^{\dagger} \\
(0.07)\end{array}$ & $\begin{array}{c}0.97 \\
(0.07)\end{array}$ & $\begin{array}{c}0.96 \\
(0.04)\end{array}$ & $\begin{array}{r}0.97 \\
(0.04)\end{array}$ \\
\hline Repurposed nonmerged school & $\begin{array}{l}1.09 \\
(0.09)\end{array}$ & $\begin{array}{c}1.01 \\
(0.09)\end{array}$ & $\begin{array}{c}1.01 \\
(0.05)\end{array}$ & $\begin{array}{c}1.08 \\
(0.04)\end{array}$ \\
\hline
\end{tabular}

All models include school buffer and month-by-year fixed effects. Sample represents 15,488 buffer-by-monthby-year observations representing 128 schools. Clustered standard errors are in parentheses. Repurposed nonschool and nonmerged school conditions were not separated due to small sample sizes. $+p<0.01,{ }^{*} p<$ 0.05 .

merger, respectively. Based on results from Tables $3-5$, school merger exhibits more expansive spatiotemporal effects on nonviolent crime than building vacancy

\section{Effects Across Closed School and Welcoming School Neighborhoods}

The results presented thus far have combined neighborhoods containing schools that officially closed with neighborhoods containing welcoming schools. Table 6 shows results from models separating merger and vacancy conditions by the two neighborhood types. I find that violent crime does not change after vacancy or 
merger for both neighborhood types across all buffer sizes. However, I find that vacancy for both neighborhood types is associated with similar decreases in nonviolent crime at the 75-meter scale and no association at larger scales. I also find that merger for both neighborhood types is associated with an increase in nonviolent crime at the 75-, 150- and 300- meter scales. In contrast to vacancy, the effect is much larger for neighborhoods with a closed school, suggesting that merger effects are more acute at the closed school's location. For example, a merger occurring in a closed school building is associated with a 55 percent increase in nonviolent crime. In comparison, the increase associated with a merger in a welcoming school's building is less than half (20 percent). Nevertheless, these results show that school closures have much broader implications for the city than what has been previously suggested by prior closure discussions, which have largely focused on closed school neighborhoods.

\section{Conclusion}

This article examines the consequences of public elementary school closures on neighborhood crime. Exploiting the methodological features of the 2013 Chicago mass closure, I compared crime rates in geographically small and homogenous areas at different spatial and temporal stages, also accounting for the potential differential associations based on school vacancy, repurposing, and merger. Several key findings emerged. First, contrary to claims made by opponents of school closures, building vacancy is associated with a decrease in local violent and nonviolent crime. I also found that nonviolent crime decreases when a school building is repurposed into a nonschool. The vacancy and repurposing effects are significant only in the neighborhood surrounding the school. These spatially localized negative effects corroborate Wo and Park's (2020) study of open elementary schools in Chicago, which found higher rates of crime only in a school's focal block. They used routine activity and social disorganization theories of crime to explain their results, which can also be applied here. My results also corroborate findings from Steinberg et al's (2019) examination of school closures in Philadelphia, which showed a reduction in crime in block groups containing closed high schools. My results expand on their findings by showing that the effects also apply to primary schools, thus moving beyond criminal opportunity theories positing students as criminal offenders.

Second, the negative effects of vacancy on both crime types are short term, persisting for less than two years for nonviolent crime and less than a year for violent crime. An explanation for this finding is that the decrease in crime due to the removal of concentrated youth is temporary, and the increase in crime related to vacancy as predicted by broken windows theory may emerge or become stronger the longer a building remains vacant. Most school districts do not establish formal plans for building repurposing after closure, leaving school buildings vacant for long durations (Dowdall and Warner 2013). My results indicate that public officials should be proactive in repurposing closed school buildings, ideally establishing a plan well before schools officially close.

Third, I find that neighborhoods with schools that merged two or more student communities experienced an increase in nonviolent crime. In contrast to the de- 
crease in crime after vacancy, the increase related to school merger is long term and spans larger spatial scales. This result suggests that the land use effects of school closure are spatiotemporally localized, whereas the student merger component has much broader community-wide consequences. Teachers and parents argue that these community-wide effects are due to conflict stemming from students being forced to cross gang boundaries when commuting to school. In deciding which schools are consolidated, district officials may not be fully accounting for these student and community safety considerations. This may be partly due to the lack of engagement during the closure process with community members who are aware of these factors. Furthermore, when a school is closed, districts may not provide teachers and staff with the type of guidance and resources that are needed to properly absorb large student populations coming from different communities. Moreover, community members beyond those formally affiliated with the schools also received little guidance and help in dealing with the potential community-wide repercussions of school merger. The CPS expanded its Safe Passage Program after the mass closure, but evidence suggests that its efficacy was limited (Curran 2019). Overall, these findings suggest that policy makers need to think not only of the unique needs of students attending schools that welcome students from closed schools but also the unique needs of the communities that these students are coming from and commuting to.

Fourth, I find that closures impact not just the neighborhoods surrounding the schools that were officially closed but also the neighborhoods surrounding the nonclosed schools that received displaced students. This is an important finding considering that school closure debates often exclusively focus on the neighborhoods of closed schools, ignoring the fact that a district's closure policy indirectly affects other neighborhoods through school relocation and student reassignment. My findings suggest that the effects of closures are much wider than previously conceived, and cost-benefit analyses of school closures should take these broader factors into account.

Several limitations of this research warrant consideration. First, the results are specific not only to Chicago but its mass school closure in 2013. The advantage of my design is that it overcomes several of the challenges in isolating the effects of school closures. As in any study, external validity is not guaranteed. Chicago, however, is a major battleground in the school closure debate, and a critical mass of school closure research focusing on Chicago already exists; thus my findings add another layer to an important case in the larger closure policy and scholarly discussion. However, future work should examine the impact of closures on local crime and other neighborhood outcomes in other cities. Second, the analysis does not examine high school closures due to the study design and does not examine heterogeneity across school characteristics such as academic performance. Third, I did not test the potential community-level mechanisms that may help explain my findings. For example, my hypothesis that the merger of students coming from communities with rival gangs explains the increase in crime after merger should be formally tested. I also do not incorporate measures of neighborhood social capital and collective efficacy to examine social disorganization predictions of changes in crime levels after school vacancy. 
These limitations notwithstanding, my findings suggest that a more complete understanding of how closures impact neighborhoods requires a reconceptualization of school closures as dichotomous events to multicategorical phenomena whose potential effects span spatiotemporal dimensions. It is not merely whether a school closes or not that matters but what happens to school facilities after closure, the implications of the closure on the surrounding neighborhood, other institutions outside of the closed school and its neighborhood that may be impacted, and how the effects vary across duration and geographic proximity. By acknowledging these broader effects, city and district officials can generate policies and make decisions that not only are designed to better allocate public funding but also ensure that existing social inequities are not exacerbated.

\section{Notes}

1 CPS voted to close 49 schools in May 2013: 47 in 2013 and 2 at a later date.

2 I coded a building as no longer vacant based on the sales date. In some cases, a building is sold but is not occupied until a much later date. This means that my estimates may be biased because these months are coded as not vacant when in fact they still are.

\section{References}

Ahmed-Ullah, Noreen. 2013. “Gang Expert Testifies School Closings Will Put Kids in Line of Fire." The Chicago Tribune, July 17. https://www . chicagotribune.com/news/ct-xpm2013-07-17-ct-met-cps-closings-hearings-20130717-story.html.

Astor, Ron Avi, Rami Benbenishty, and Heather Ann Meyer. 2004. “Monitoring and Mapping Student Victimization in Schools." Theory into Practice 43:39-49. https : //doi . org/10. 1207/s15430421tip4301_6.

Black, Curtis. 2018. "Chicago School Policy Is a Driver of Neighborhood Violence, Advocates Say." The Chicago Reporter, January 18. https://www . chicagoreporter . com/on - englewood - school - closing - proposals - district - still - not - listening to-residents/.

Brazil, Noli. 2016. "The Effects of Social Context on Youth Outcomes: Studying Neighborhoods and Schools Simultaneously." Teachers College Record 118:1-30.

Brazil, Noli. 2019. “The Effects of Public Elementary School Closures on Neighborhood Housing Values in US Metropolitan Areas, 2000-2010." Pp. 231-58 in Shuttered Schools: Race, Community, and School Closures in American Cities, edited by E. Duncan-Shippy. Charlotte, NC: Information Age Publishing.

Brummet, Quentin. 2014. "The Effect of School Closings on Student Achievement." Journal of Public Economics 119:108-24. https : //doi.org/10.1016/j.jpubeco.2014.06.010.

Burdick-Will, Julia, Micere Keels, and Todd Schuble. 2013. “Closing and Opening Schools: The Association between Neighborhood Characteristics and the Location of New Educational Opportunities in a Large Urban District." Journal of Urban Affairs 35:59-80. https://doi.org/10.1111/juaf.12004. 
Burdick-Will, Julia, Marc L. Stein, and Jeffrey Grigg. 2019. "Danger on the Way to School: Exposure to Violent Crime, Public Transportation, and Absenteeism." Sociological Science 6:118-42. https://doi.org/10.15195/v6.a5.

Caven, Meg. 2019. "Quantification, Inequality, and the Contestation of School Closures in Philadelphia." Sociology of Education 92:21-40. https://doi .org/10.1177/ 0038040718815167.

Chicago Educational Facilities Task Force. 2014. “The Report of the Illinois General Assembly's Chicago Educational Facilities Task Force 2012-2013." Illinois General Assembly. https://www.isbe.net/Documents/ceftf-annual-rpt12-13.pdf.

Cook, Philip J. 2017. "The Demand and Supply of Criminal Opportunities." Pp. 127-53 in Crime Opportunity Theories. Abingdon, United Kingdom: Routledge.

Cui, Lin, and Randall Walsh. 2015. "Foreclosure, Vacancy and Crime." Journal of Urban Economics 87:72-84. https://doi.org/10.1016/j.jue.2015.01.001.

Curran, F. Chris. 2019. "Does the Chicago Safe Passage Program Reduce Reported Crime around Elementary Schools? Evidence from Longitudinal, Geocoded Crime Data." Criminal Justice Policy Review 30:1385-407. https : //doi .org/10.1177/0887403418812125.

DaViera, Andrea L., and Amanda L. Roy. 2019. “Chicago Youths' Exposure to Community Violence: Contextualizing Spatial Dynamics of Violence and the Relationship With Psychological Functioning." American Journal of Community Psychology, first published December 2 as https://doi.org/10.1002/ajcp. 12405.

De la Torre, Marisa, Molly Gordon, Paul Moore, and Jennifer Cowhy. 2015. School Closings in Chicago. Chicago, IL: Consortium on Chicago School Research.

Dowdall, Emily, and Susan Warner. 2013. "Shuttered Public Schools: The Struggle to Bring Old Buildings New Life." Pew Charitable Trusts Philadelphia Research Initiative.

Engberg, John, Brian Gill, Gema Zamarro, and Ron Zimmer. 2012. "Closing Schools in a Shrinking District: Do Student Outcomes Depend on Which Schools Are Closed?" Journal of Urban Economics 71:189-203. https : //doi .org/10 .1016/j · jue.2011 .10.001.

Ewing, Eve L. 2018. Ghosts in the Schoolyard: Racism and School Closings on Chicago's South Side. Chicago, IL: University of Chicago Press. https://doi.org/10.7208/chicago/ 9780226526331.001 .0001$.

Felson, Marcus. 1987. "Routine Activities and Crime Prevention in the Developing Metropolis." Criminology 25:911-32.

Good, Ryan M. 2019. “Neighborhood Schools and Community Development: Revealing the Intersections through the Philadelphia School Closure Debate." Journal of Planning Education and Research, first published April 2 as https://doi.org/10.1177/ $0739456 \times 19839769$.

Gordon, Molly, Marisa de la Torre, Jennifer Cowhy, Paul Moore, Lauren Sartain, and David Knight. 2018. "School Closings in Chicago: Staff and Student Experiences and Academic Outcomes." University of Chicago Consortium. https : //consortium.uchicago . edu/sites/default/files/2018-10/School\%20Closings\%20in\%20Chicago-May 2018 Consortium.pdf. 
Hagedorn, John M. 2017. "Gangs, Schools, and Social Change: An Institutional Analysis." The Annals of the American Academy of Political and Social Science 673:190-208. https: //doi.org/10.1177/0002716217726965.

Han, Hye-Sung. 2014. "The Impact of Abandoned Properties on Nearby Property Values." Housing Policy Debate 24:311-34. https : //doi .org/10.1080/10511482 .2013.832350.

Kautt, Paula M., and Dennis W. Roncek. 2007. “Schools as Criminal 'Hot Spots' Primary, Secondary, and Beyond." Criminal Justice Review 32:339-57. https ://doi . org/10 .1177/ 0734016807311559.

Konkol, Mark. 2013. "Gang Curse a Reality for CPS Kids as Schools Close." DNA Info, March 22. https://www. dnainfo.com/chicago/20130322/old-town/cps-school-closingsput-focus-on-gang-territories-neighborhoods/.

Lee, Jin, and Christopher Lubienski. 2017. "The Impact of School Closures on Equity of Access in Chicago." Education and Urban Society 49:53-80. https://doi .org/10.1177/ 0013124516630601.

McFarland, Joel, Bill Hussar, Cristobal De Brey, Tom Snyder, Xiaolei Wang, Sidney WilkinsonFlicker, Semhar Gebrekristos, Jijun Zhang, Amy Rathbun, Amy Barmer, Farrah Bullock Mann, Serena Hinz, Thomas Nachazel, Wyatt Smith, and Mark Ossolinski. 2017. “The Condition of Education 2017. NCES 2017-144." National Center for Education Statistics. https: //nces.ed.gov/pubsearch/pubsinfo . asp?pubid=2017144.

Papachristos, Andrew V., Noli Brazil, and Tony Cheng. 2018. "Understanding the Crime Gap: Violence and Inequality in an American City." City \& Community 17:1051-74. https : //doi.org/10.1111/cico.12348.

Papachristos, Andrew V., David M. Hureau, and Anthony A. Braga. 2013. "The Corner and the Crew: The Influence of Geography and Social Networks on Gang Violence." American Sociological Review 78:417-47. https://doi .org/10.1177/0003122413486800.

Raleigh, Erica, and George Galster. 2015. "Neighborhood Disinvestment, Abandonment, and Crime Dynamics." Journal of Urban Affairs 37:367-96. https ://doi .org/10.1111/juaf . 12102.

Roncek, Dennis W. 2000. “Schools and Crime." Pp. 153-65 in Analyzing Crime Patterns: Frontiers of Practice, edited by V. Goldsmith, P. G. McGuire, J.H. Mollenkopf, and T.A. Ross. Thousand Oaks, CA: Sage Publications.

Sampson, Robert J., and W. Byron Groves. 1989. “Community Structure and Crime: Testing Social-Disorganization Theory." American Journal of Sociology 94:774-802. https://doi . org/10.1086/229068.

Sarrio, Jaime. 2012. "Parents Fear Impact of Empty Atlanta School Buildings." The Atlanta Journal-Constitution, April 5. https ://www . ajc.com/news/local/parents-fear-impactempty-atlanta-school-buildings/mOMJRerM9mYqzXuiF6heVL/.

Sharkey, Patrick, Amy Ellen Schwartz, Ingrid Gould Ellen, and Johanna Lacoe. 2014. “High Stakes in the Classroom, High Stakes on the Street: The Effects of Community Violence on Student's Standardized Test Performance." Sociological Science 1:199. https://doi .org/ 10.15195/v1.a14.

Spelman, William. 1993. "Abandoned Buildings: Magnets for Crime?" Journal of Criminal Justice 21:481-95. https ://doi .org/10.1016/0047-2352(93)90033-j. 
Steinberg, Matthew P., Benjamin Ukert, and John M. MacDonald. 2019. "Schools as Places of Crime? Evidence from Closing Chronically Underperforming Schools." Regional Science and Urban Economics 77:125-40. https ://doi .org/10.1016/j .regsciurbeco.2019.04 . 001.

Tieken, Mara Casey, and Trevor Ray Auldridge-Reveles. 2019. "Rethinking the School Closure Research: School Closure as Spatial Injustice." Review of Educational Research 89:917-53. https://doi.org/10.3102/0034654319877151.

Weber, Rachel, Stephanie Farmer, and Mary Donoghue. 2020. “Predicting School Closures in an Era of Austerity: The Case of Chicago." Urban Affairs Review 56:415-50. https : //doi.org/10.1177/1078087418802359.

Willits, Dale, Lisa Broidy, and Kristine Denman. 2013. "Schools, Neighborhood Risk Factors, and Crime." Crime E Delinquency 59:292-315. https://doi .org/10.1177/ 0011128712470991.

Wilson, James Q., and George L. Kelling. 1982. “Broken Windows.” Atlantic Monthly 249:29_ 38.

Wo, James C., and Jihye Park. 2020. "An Examination of Schools, Social Ecological Factors, and Neighbourhood Crime." The British Journal of Criminology, first published February 3 as https://doi.org/10.1093/bjc/azaa002.

Acknowledgments: I thank Luis Guarnizo, Andrew Papachristos, and Jenna Stearns for generously reading previous versions and providing invaluable feedback. I also thank Enrica Jiang for data collection and research assistance. Any remaining errors are mine alone.

Noli Brazil: Department of Human Ecology, University of California, Davis. E-mail: nbrazil@ucdavis.edu. 